\title{
PENGARUH PERILAKU KONSUMTIF, JENIS KELAMIN, DAN PENDAPATAN TERHADAP PENGELOLAAN KEUANGAN PRIBADI KARYAWAN DIVISI GARMENT PT DAN LIRIS SUKOHARJO
}

\author{
Devy Nirmala Sari Indarto \\ Program Studi Manajemen Fakultas Ekonomi Universitas Kristen Surakarta \\ devynirmala07@gmail.com \\ Kristyana Dananti \\ Program Studi Manajemen Fakultas Ekonomi Universitas Kristen Surakarta \\ kristianadananti@gmail.com
}

Masuk : 08-01-2021, revisi : 19-03-2021, diterima untuk diterbitkan : 22-03-2021

\begin{abstract}
The development of online marketing facilitates promotion and increases interest in shoping for male and female consumers. The interest in shoping become a problem in management of personal finance, when income is limited. Especially for group of people who receive income as emlpoyees. The puprpose of this article explains the influence of consumptive behavior, gender, and income on management of employee personal finances in the garment division of PT Dan Liris Sukoharjo. This study uses standardized linier regression models. The data analyzed came from convenience sampling method. The sample size is 43 employees. Data collection was done by quesionnaires. The data is processed using SPSS 16.0 software. The result of the analysis show that income has a significant effect on management of employee personal finances while consumptive behavior and gender have no significant efect on management of employee personal finances. However, together it was found that there was a significant influence on consumptive behavior, gender and income on management of employee personal finances.
\end{abstract}

Keywords: Consumptive Behaviour, Gender, Income, Management Of Personal Finances, Employees

\begin{abstract}
Abstrak: Berkembangnya pemasaran online memudahkan promosi dan meningkatkan minat untuk membeli bagi konsumen pria dan wanita. Minat membeli barang-barang konsumtif menjadi masalah dalam pengelolaan keuangan pribadi ketika pendapatan terbatas, terutama untuk kelompok masyarakat yang menerima pendapatan sebagai karyawan. Tujuan artikel ini untuk menjelaskan pengaruh perilaku konsumtif, jenis kelamin, pendapatan terhadap pengelolaan keuangan pribadi karyawan divisi garment PT Dan Liris Sukoharjo. Penelitian ini menggunakan model regresi linier yang distandarisasi. Sampel sebanyak 43 karyawan ditarik dengan menggunakan metode convenience sampling. Pengumpulan data dilakukan dengan mengumpulkan kuesioner. Data diolah dengan menggunakan software SPSS 16.0. Hasil analisis menunjukkan pendapatan berpengaruh signifikan terhadap pengelolaan keuangan pribadi karyawan, sedangkan perilaku konsumtif dan jenis kelamin secara parsial tidak berpengaruh signifikan terhadap pengelolaan keuangan karyawan. Namun demikian, secara bersama ditemukan hasil terdapat pengaruh signifikan perilaku konsumtif, jenis kelamin dan pendapatan terhadap pengelolaan keuangan pribadi.
\end{abstract}

Kata kunci: Perilaku Konsumtif, Jenis Kelamin, Pendapatan, Pengelolaan Keuangan Pribadi, Karyawan

\section{PENDAHULUAN}

Merambahnya pemasaran barang dan jasa ke dalam dunia maya membuat orang semakin mudah berbelanja dan melakukan transaksi jual beli. Hal tersebut menjadikan manusia semakin 
mudah untuk mencapai kebutuhan serta keinginannya. Adanya peristiwa ini membentuk manusia cenderung semakin konsumtif (Adlinamasyita.wordpress.com, 2015). Perilaku konsumtif ini, bila dibiarkan terus menerus dapat menjadi gaya hidup konsumsi masyarakat Indonesia.

Pria maupun wanita di era ini memiliki kebutuhan dan keinginan yang sangat banyak. Namun dalam kenyataannya, pria cenderung lebih mampu mengontrol kebutuhan dan keuangannya serta melihat lebih rasional daripada wanita yang cenderung hanya melihat dari yang mereka suka tanpa melihat fungsi dan kegunaannya. Dilihat dari Liputan6.com (2016), tentang perbedaan pria dan wanita saat mengelola keuangan, wanita lebih hebat dari pria dalam hal mengelola utang pribadi dan wanita punya strategi lebih baik tetapi kepercayaan diri mereka kurang. Sedangkan pria menyimpan lebih banyak dana darurat dan menyimpan lebih banyak uang untuk pensiun mereka. Dalam kehidupan, antara pria dan wanita yang menjadi persoalan utama adalah keuangan. Terlebih di dalam rumah tangga mengelola atau mengatur keuangan untuk menentukan alokasi dana, terkadang tidak berjalan sesuai rencana dan bahkan tidak jarang sudah habis di tengah-tengah bulan. Menurut Yusanti (2020) jenis kelamin berpengaruh secara signifikan terhadap literasi keuangan. Hasil tersebut didukung oleh penelitian dari Nujmatul (2016) menunjukkan bahwa literasi keuangan memiliki pengaruh yang signifikan terhadap perilaku keuangan mahasiswa akan tetapi gender, usia, kemampuan akademis dan pengalaman kerja tidak terbukti memiliki korelasi dengan perilaku keuangan mahasiswa. Tetapi berbanding terbalik dengan pendapat Hadjali dalam Herlindawati (2015) mengatakan bahwa bahwa jenis kelamin, lingkungan belanja, petunjuk penjualan, individualisme dan harga tidak mememiliki pengaruh terhadap pengelolaan keuangan pribadi seseorang dalam mengatur pengeluarannya/keputusan membeli. Dari hasil pendapat di atas, sangat penting untuk mengetahui dan paham akan pengelolaan keuangan pribadi.

Pendapatan yang diperoleh dengan jabatan sebagai staff adalah dari gaji bulanan mereka sendiri. Menurut Herlindawati (2015) Pendapatan dapat didefinisikan sebagai jumlah seluruh uang yang diterima oleh seseorang atau rumah tangga selama jangka waktu tertentu (biasanya satu tahun). Pendapatan dapat berupa upah/gaji, atau penerimaan tenaga kerja, pendapatan dari kekayaan seperti sewa, bunga dan deviden, serta pembayaran transfer atau penerimaan dari pemerintah seperti tujangan sosial (misal beasiswa) atau asuransi pengangguran. Beberapa karyawan menganggap cukup atau lebih dan beberapa menganggap masih kurang. Tetapi tidak sedikit pula dari mereka memiliki pekerjaan sampingan seperti mencoba; online shop, berjualan pulsa, simpan pinjam, dll. Hal tersebut dilakukan karena mereka ingin menambah penghasilan mereka, menyalurkan hobby dan passion, memiliki target keuangan, menambah jaringan networking yang lebih luas, sebagai pengisi waktu luang, serta mempersiapkan pensiun untuk di hari tua. Apalagi, dengan canggihnya media sosial di masa ini, mencari tambahan penghasilan menjadi hal yang sangat mudah. Pendapatan juga sangat penting bila karyawan berhenti bekerja, contohnya adalah wanita yang baru saja melahirkan biasanya memilih untuk pensiun dini dan mengurus rumah tangga. Alhasil peran pria yang akhirnya menjadi tulang punggung tunggal. Perubahan keuangan pasti berdampak bagi situasi keluarga. Tetapi, hasil berbeda ditunjukan oleh Hakim (2017), bahwa income berpengaruh negatif terhadap financial management behavior. Beberapa hal ini yang dapat menjadi acuan untuk karyawan melakukan pengelolaan keuangan dengan merevisi, mencadangkan, mengevaluasi, serta melindungi keuangan mereka. Karyawan di PT Dan Liris Sukoharjo khususnya staff divisi garment memiliki kecenderungan terhadap gaya hidup konsumtif dalam berbelanja online, gemar menggunakan kartu kredit, memiliki gaji di atas UMR tetapi belum memiliki rumah serta, karena sebagian berstatus lajang para karyawan sering melewatkan/ tidak berfikir untuk berinvestasi. Untuk itu, menarik untuk menganalisis pengaruh perilaku konsumtif, jenis kelamin, dan pendapatan terhadap pengelolaan keuangan pribadi study kasus pada karyawan staff divisi garment PT Dan Liris Sukoharjo. 


\section{TELAAH PUSTAKA}

Perilaku konsumtif merupakan tindakan individu sebagai konsumen untuk membeli, menggunakan atau mengkonsumsi barang atau jasa secara berlebihan, tidak rasional, menimbulkan pemborosan dan hanya mengutamakan keinginan atau kesenangan tanpa mempertimbangkan kebutuhan atau manfaat dari barang atau jasa tersebut, bahkan hanya untuk memperoleh pengakuan sosial, mengikuti mode, atau kepuasan pribadi (kajianpustaka.com, 2018). Ciri-ciri sederhana yang terlihat jelas yaitu membeli barang bukan karena butuh, tetapi karena ingin, membeli barang karena diskon, bukan karena penting, bangga dengan memakai barang bermerk terkenal (branded), walau harga melangit, gelisah saat tidak ke mal untuk shopping, resah saat uang sedikit, menyelesaikan semua hal dengan uang.

Sebuah studi mengungkapkan bahwa laki-laki lebih pandai dalam mengelola keuangan dibandingkan dengan perempuan. Hal ini mengindikasikan bahwa laki-laki lebih memiliki kepercayaan yang tinggi dalam membuat keputusan keuangan dibandingkan dengan perempuan yang lebih cenderung risk averse dibandingkan dengan laki-laki (Wagland dan Taylor dalam Nujmatul, 2016). Gender atau jenis kelamin diidentifikasi sebagai salah satu faktor yang mempengaruhi financial management behavior. Diduga jenis kelamin laki-laki lebih baik dalam melakukan manajemen keuangan. Mengingat seorang laki-laki mempunyai pemikiran terkait masa depan dan menjadi kepala rumah tangga kelak.

Pada penelitian ini akan fokus pada pendapatan yang dihasilkan oleh perorangan atau pribadi. Pendapatan dapat didefinisikan sebagai jumlah seluruh uang yang diterima oleh seseorang atau rumah tangga selama jangka waktu tertentu (biasanya satu tahun). Pendapatan terbagi menjadi 2 bagian, yaitu pendapatan aktif dan pasif. Pendapatan aktif adalah pendapatan yang dihasilkan dari pekerjaan yang dilakukan. Sedangkan, pendapatan pasif adalah pendapatan yang diterima dari hasil pekerjaan pihak lain (finansialku.com, 2013).

Mengelola keuangan pribadi merupakan salah satu aplikasi dari konsep manajemen keuangan pada level individu. Manajemen keuangan yang meliputi aktivitas perencanaan, pengelolaan dan pengendalian keuangan, sangatlah penting untuk mencapai https://ojs.unud.ac.id/index.php/EEB/AuthorGuidelinekesejahteraan finansial. Aktivitas perencanaan meliputi kegiatan untuk merencanakan alokasi pendapatan yang diperoleh akan digunakan untuk apa saja. Pengelolaan merupakan kegiatan untuk mengelola keuangan secara efisien sedangkan pengendalian merupakan kegiatan untuk mengevaluasi pengelolaan keuangan sudah sesuai dengan yang direncanakan/dianggarkan. Widayati dalam Nujmatul (2016) mengatakan bahwa keputusan keuangan yang diambil oleh seorang individu meliputi jumlah uang yang harus dikonsumsi tiap periode, kelebihan yang diinvestasikan serta cara mendanai investasi dan konsumsi. Perilaku keuangan yang sehat ditunjukkan oleh aktivitas perencanaan, pengelolaan serta pengendalian keuangan yang baik. Indikator perilaku keuangan yang baik dapat dilihat dari cara / sikap seseorang dalam mengelola keluar masuknya uang, manajemen kredit, tabungan dan investasi (Hilgert dan Hogart, 2003) dalam Herlindawati (2015).

\section{METODE PENELITIAN}

Penelitian dilakukan terhadap karyawan garment PT Dan Liris Sukoharjo, yang beralamat di Kelurahan Banaran, Kecamatan Grogol, Kabupaten Sukoharjo. Populasi yang diteliti adalah berjumlah 150 orang sedangkan sampel diambil dengan metode convenience sampling, berjumlah 43 orang. Data dikumpulkan menggunakan kuesioner dengan skala likert. Metode analisis data dilakukan dengan urutan:

1. Melakukan uji instrumen untuk menguji validitas dan reliabilitas kuesioner sebagai alat untuk mengumpulkan data.

2. Membentuk Model Regresi menggunakan Standardizied Regression Model dengan persaman $\mathrm{Y}=\beta 1 \mathrm{X} 1+\beta 2 \mathrm{X} 2+\beta 3 \mathrm{X} 3+\mathrm{e}$ 
3. Melakukan pengujian asumsi klasik model regresi untuk memastikan model regresi tdak mengalami penyimpangan sehingga dapat digunakan untuk melakukan prediksi

4. Melakukan pengujian hipotesis untuk mmbuat kesimpulan menerima atau menolak pengaruh variabel bebas terhadap variabel terikat baik secara parsial maupin secara simultan.

\section{ANALISIS DAN PEMBAHASAN \\ Uji Instrumen Data}

Uji instrumen dilakukan dengan uji validitas internal yag diukur dengan pearson correlation product moment dan reliabilitas yang diukur dengan nilai alpha cronbach dengan hasil sebagai berikut:

Tabel 1

Hasil Uji Validitas dan Reliabilitas Variabel

\begin{tabular}{|l|l|l|l|}
\hline No & Variabel & Jumlah Item Pertanyaan & Reliablitas \\
\hline 1. & Perilaku Konsumtif & 10 & kuat \\
\hline 2. & Jenis Kelamin & 1 & $*$ \\
\hline 3. & Pendapatan & 1 & $*$ \\
\hline 4. & Pengelolaan Keuangan Pribadi & 19 & kuat \\
\hline
\end{tabular}

* tidak dilakukan uji reliabilitas karena item pertanyaan hanya satu

Sumber: data diolah

\section{Persamaan Model Regresi}

Data yang diolah menggunakan SPSS 16.0 menghasilkan output sebagai berikut:

Keterangan:

$$
\mathrm{Y}=0,220 \mathrm{X}_{1}+0,023 \mathrm{X}_{2}+0,366 \mathrm{X}_{3}+\mathrm{e}
$$

$\mathrm{Y}=$ Pengelolaan Keuangan Pribadi

$\mathrm{X} 1=$ Perilaku Konsumtif

$\mathrm{X} 2$ = Jenis Kelamin

$\mathrm{X} 3=$ Pendapatan

$\mathrm{e}=$ error

\section{Uji Asumsi Klasik}

Hasil uji normalitas terhadap variabel perilaku konsumtif, pendapatan, dan pengelolaan keuangan pribadi berdistribusi normal. Sedangkan untuk jenis kelamin tidak dapat diuji, karena hanya memiliki 2 klasifikasi yaitu laki-laki dan perempuan. Hasil uji multikolinieritas yang didapat dari uji ini adalah tolerance jenis kelamin 0.846, perilaku konsumtif 0.972 , pendapatan 0.853. Maka, dapat diketahui bahwa hasil dari uji multikolinearitas ini adalah bebas multikolinearitas. Uji heteroskedastisitas dilakukan dengan uji Park, menunjukkan semua variabel bebas yang yang dimasukkan ke dalam model memiliki nilai sig lebih besar dari batas kesalahan yang digunakan sebesar 5\% sehingga tidak mengandung heteroskedastisitas.

\section{Uji Hipotesis}

Berdasarkan signifikansi nilai t pada koefisien model regresi yang telah dihasil, jenis kelamin 0.887 perilaku konsumtif 0.142 dan pendapatan 0.025 maka secara parsial jenis kelamin dan perilaku konsumtif tidak signifikan karena hasil lebih dari 0.05 sehingga $\mathrm{Ha}$ ditolak. Dan pendapatan memiliki hasil yang signifikan karena kurang dari 0.05 maka Ha diterima.

Hasil pengujian pengaruh perilaku konsumtif, jenis kelamin dan pendapatan secara bersama terhadap pengelolaan keuangan pribadi menghasilkan nilai signifikansi $\mathrm{F}$ sebesar 0,05 maka Ha diterima, artinya variabel perilaku konsumtif, jenis kelamin dan pendapatan secara bersama berpengaruh signifikan terhadap pengelolaan keuangan pribadi.

\section{KESIMPULAN DAN SARAN}

Berdasarkan hasil dari pembahasan dan pengolahan data di atas, maka dapat disimpulkan bahwa perilaku konsumtif dan jenis kelamin tidak berpengaruh signifikan terhadap 
pengelolaan keuangan pribadi karyawan staff divisi garment PT Dan Liris Sukoharjo. Sedangkan pendapatan berpengaruh signifikan terhadap pengelolaan keuangan pribadi karyawan staff divisi garment PT Dan Liris Sukoharjo. Namun demikian, perilaku konsumtif, jenis kelamin dan pendapatan berpengaruh signifikan terhadap pengelolaan keuangan pribadi karyawan staff divisi garment PT Dan Liris Sukoharjo secara simultan. Berdasarkan kesimpulan, beberapa saran yang bisa penulis sampaikan bagi karyawan perusahaan PT Dan Liris Sukoharjo: untuk para karyawan baik pria maupun wanita untuk meminimalisir gaya hidup konsumtif dengan cara, memisahkan kebutuhan pribadi dengan keinginan, mengurangi penggunaan utang, memanfaatkan sebagaian pendapatan yang diterima untuk menghasilkan lebih banyak pendapatan. Para karyawan sebaiknya menggunakan uang yang dimiliki untuk keperluan yang benar-benar penting. Untuk penelitian berikutnya sebaiknya ditambahkan variabel lain agar meningkatkan koefisien determinasi sebagai kesesuaian model, serta menambah responden dalam penelitian agar hasil yang didapat lebih baik.

\section{DAFTAR PUSTAKA}

Hakim, I. M. (2017). Pengaruh Financial Knowledge, Income, dan Financial Attitude terhadap Financial Management Behaviour pada Pengusaha Bordir Kota Tasikamalaya. Jurnal Manajemen Universitas Siliwangi, 6(2). Diunduh, 20 September 2018 pukul 20.26 WIB

Herlindawati, D. (2015). Pengaruh Kontrol Diri, Jenis Kelamin, dan Pendapatan terhadap Pengelolaan Keuangan Pribadi Mahasiswa Pascasarjana Universitas Negeri Surabaya, diunduh 20 September 2018 pukul 8.14 WIB.

Nujmatul, L. (2016). Pengaruh Literasi Keuangan terhadap Perilaku Mahasiswa dalam Mengelola Keuangan. Diunduh, 16 September 2018 pukul 10.16 WIB.

Yusanti, A. P. (2020). Pengaruh Gaya Hidup, Kecerdasan Spiritual dan Jenis Kelamin terhadap Perilaku Pengelolaan Keuangan Keluarga. Artikel Ilmiah Sekolah Tinggi Perbanas Surabaya http://eprints.perbanas.ac.id/6591/49/ARTIKEL\%20ILMIAH.pdf diunduh 1 Desember 2020 pukul 20.30 WIB.

Adlinamasyita.wordpress.com/2015/01/11/budaya-konsumtif-di-indonesia-gaya-hidupmasyarakat-global/ diunduh 1 Desember 2018 pukul $20.00 \mathrm{WIB}$

https://www.finansialku.com/5-jenis-pendapatan-pasif/ diunduh 1 Desember 2018 pukul 17.00 WIB.

https://www.kajianpustaka.com/2018/06/pengertian-aspek-dan-karakteristik-perilakukonsumtif diunduh 1 Desemeber 2018 pukul 17.30 WIB.

https://www.liputan6.com/bisnis/read/2519424/perbedaan-pria-dan-wanita-saat-atur-uang diunduh 1 Desember 2018 pukul 18.15 WIB. 